\title{
Progressive spastic paraparesis in a girl with short stature
}

\author{
Indar Kumar Sharawat, ${ }^{1}$ Renu Suthar, ${ }^{\oplus 1}$ Naveen Sankhyan, ${ }^{1}$ Pratibha Singhi ${ }^{2}$
}

'Department of Pediatrics, Post Graduate Institute of Medical Education and Research (PGIMER), Chandigarh, India ${ }^{2}$ Department of Pediatrics, Medanta, The Medicity, Gurgaon, Haryana, India

Correspondence to Dr Renu Suthar, drrenusuthar@gmail.com

Accepted 13 May 2019

\section{DESCRIPTION}

A 3-year-old-girl, born to non-consanguineous parents at term with an uncomplicated perinatal period, presented with progressive walking difficulty from 18 months of age. She was noticed to walk with a lordotic gait and frequent falls. Examination revealed short stature $(81.6 \mathrm{~cm}, \leq 3$ $\mathrm{z}$-score), frontal bossing, flat nasal bridge, wrist widening, short neck, scoliosis, genu valgum (figure 1) and spastic paraparesis. Her head circumference, intellect, vision and hearing were normal, and there was no bladder and bowel involvement. She received vitamin D supplements multiple times for suspected vitamin D-resistant rickets given wrist widening and genu valgum deformities. Skeletal survey showed dysostosis multiplex (figure 2). MRI of spine showed odontoid hypoplasia and narrowing of the thoracic spinal canal. Diagnoses of mucopolysaccharidosis (MPS type 4), mucolipidosis type II or III, $\alpha$-mannosidosis and skeletal dysplasia (spondyloepiphyseal dysplasia) were considered. Urinary glycosaminoglycans assay showed presence of keratan sulfate and $\mathrm{N}$-acetylgalactosamine-6-sulfatase enzyme assay showed complete absence, confirming the diagnosis of MPS type IVA.

Facial dysmorphism, short stature and dysostosis multiplex pointed towards the diagnosis of MPS type IVA in the index child, also known as Morquio's syndrome. Skeletal dysplasia and skeletal dysostosis are the two conditions, can present

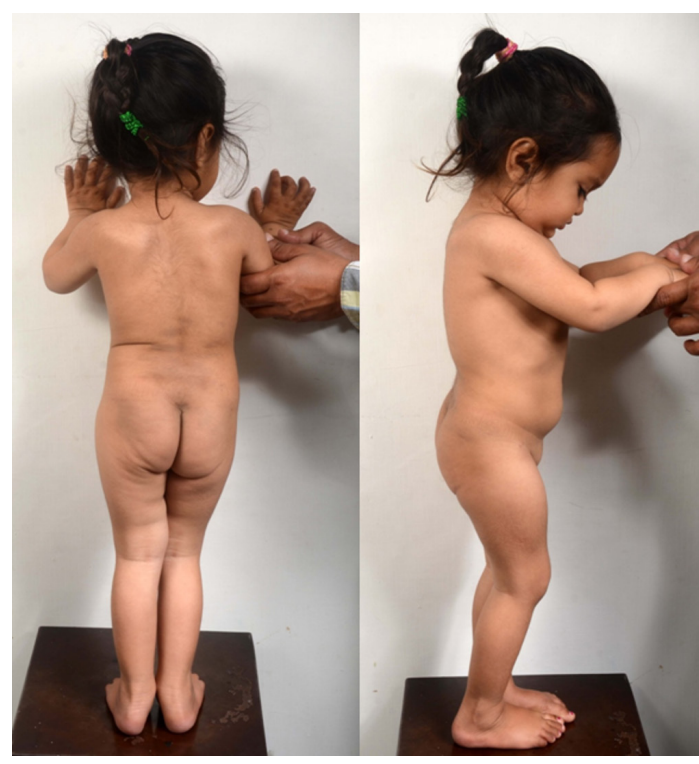

Figure 1 Clinical photograph of the child showing short stature, short neck, thoracolumbar kyphoscoliosis, mongolian spots and knock knee.

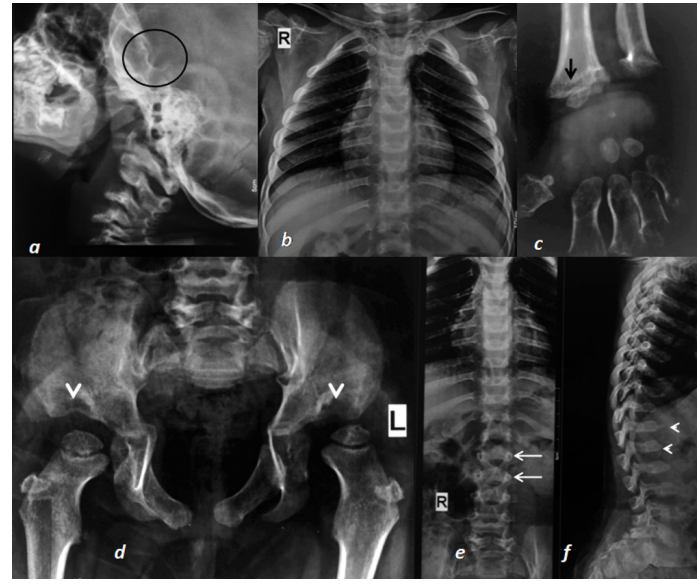

Figure 2 Skeletal X-rays of index patient with mucopolysaccharidosis type IVA. X-ray skull and cervical spine (A) showing widened and slant sella, cervical vertebrae are flat with normal disc height. Skeletal X-rays showed generalised osteopaenia, anteriorly expanded and spatulated ribs (B), radial epiphysial dysplasia (black arrow), proximal pointing of metacarpals, delayed bone age (C), acetabular epiphysial dysplasia (arrowhead) (D), platyspondyly (arrow) (E) and anterior beaking at the lumbar vertebrae (arrowhead) (F).

with short stature, bone and cartilage abnormalities. ${ }^{1}$ Skeletal dysplasias are disorders of growth of bones, cartilages and tend to evolve with age, and often involve the epiphyses and spine. Dysostosis multiplex includes single or multiple bones and develops due to impaired blastogenesis in utero, and the course remains static throughout life. Spondyloepiphyseal dysplasia closely mimics the dysostosis multiplex, has involvement of epiphyses and spine with atlantoaxial instability, odontoid hypoplasia and platyspondyly. ${ }^{2}$ However, widespread changes in the skull bones, sella, long bones and central anterior beaking of the vertebrae is characteristic of MPS type IVA.

MPS type IVA is a rare lysosomal storage disorder caused by the deficiency of enzyme $\mathrm{N}$-acetylgalactosamine-6-sulfatase. ${ }^{3}$ MPS type IVA causes skeletal dysplasia through excessive storage of keratan sulfate in bones. Patients with Morquio syndrome usually present by the second or third years of life with short trunk dwarfism, bone deformities like odontoid hypoplasia, vertebral anomalies, pectus carinatum, kyphosis, scoliosis, genu valgum, coxa valga, flaring of the lower ribs, hypermobile joints and abnormal gait with a tendency to fall. ${ }^{3}$ Patients with MPS type IVA characteristically have preserved intelligence and unique skeletal manifestations. 
The most critical skeletal deformity is odontoid hypoplasia, in combination with ligamentous laxity results in atlantoaxial subluxation, cervical myelopathy or even death. Spinal instability with resultant myelopathy causes spastic paraparesis. Excessive accumulation of glycosaminoglycans in vertebrae and soft tissues, and progressive stenosis is the other mechanism of spinal compression. Patients with a severe phenotype often do

\section{Learning points}

- Skeletal dysplasia and skeletal dysostosis, both present with short stature, bone and cartilage abnormalities.

- Mucopolysaccharidosis (MPS) type IVA causes dysostosis multiplex through excessive storage of keratan sulfate in the bones.

- Widespread skeletal changes involving the skull bones, sella, long bones, spine and central anterior beaking of vertebrae are characteristic features of MPS type IVA.

- MPS type IVA may be misdiagnosed as refractory rickets due to the presence of frontal bossing, wrist widening and short stature. not survive beyond the second or third decade of life, which is primarily related to cervical instability and pulmonary compromise. Management includes spine stabilisation, discoidectomy and enzyme replacement therapy.

Contributors IKS: patient management, literature review and initial draft of manuscript preparation. RS: analysis of radiology, critical review of manuscript for important intellectual content and final approval of the version to be published. NS: clinician in charge, critical review of manuscript for important intellectual content and final approval of the version to be published. PS: critical review of manuscript for important intellectual content and final approval of the version to be published.

Funding The authors have not declared a specific grant for this research from any funding agency in the public, commercial or not-for-profit sectors.

Competing interests None declared.

Patient consent for publication Parental/guardian consent obtained.

Provenance and peer review Not commissioned; externally peer reviewed.

\section{REFERENCES}

1 Panda A, Gamanagatti S, Jana M, et al. Skeletal dysplasias: A radiographic approach and review of common non-lethal skeletal dysplasias. World J Radiol 2014;6:808-25.

2 Nicolas-Jilwan M, AlSayed M. Mucopolysaccharidoses: overview of neuroimaging manifestations. Pediatr Radiol 2018;48:1503-20.

3 Montaño AM, Tomatsu S, Gottesman GS, et al. International Morquio A Registry: clinical manifestation and natural course of Morquio A disease. I Inherit Metab Dis 2007:30:165-74.

Copyright 2019 BMJ Publishing Group. All rights reserved. For permission to reuse any of this content visit https://www.bmj.com/company/products-services/rights-and-licensing/permissions/

BMJ Case Report Fellows may re-use this article for personal use and teaching without any further permission.

Become a Fellow of BMJ Case Reports today and you can:

- Submit as many cases as you like

- Enjoy fast sympathetic peer review and rapid publication of accepted articles

- Access all the published articles

Re-use any of the published material for personal use and teaching without further permission

Customer Service

If you have any further queries about your subscription, please contact our customer services team on +44 (0) 2071111105 or via email at support@bmj.com.

Visit casereports.bmj.com for more articles like this and to become a Fellow 